\title{
Social Responsibility of Consumer Case of Products from the Social Economy in Morocco
}

\author{
Bouchra Lebzar ${ }^{1}$, Mohamed Larbi Sidmou ${ }^{1} \&$ Rachid Jahidi $^{2}$ \\ ${ }^{1}$ Cadi Ayyad University, Marrakesh, Morocco \\ ${ }^{2}$ Hassan $1{ }^{\text {st }}$ University, Settat, Morocco \\ Correspondence: Bouchra Lebzar, Cadi Ayyad University, Marrakesh, Morocco. E-mail: b_lebzar@yahoo.fr
}

Received: February 27, 2012 Accepted: March 12, 2012 Online Published: July 1, 2012

doi: 10.5539/ibr.v5n7p56 URL: http://dx.doi.org/10.5539/ibr.v5n7p56

\begin{abstract}
Investigations conducted in this research aim to understand the socially responsible behavior in the Moroccan context. The study focused on the consumption of fair trade products from the social economy. The results relate to the attitudes and motivations towards these products. Finally, a typology is proposed to generate profiles of consumers who are qualified from buying motives.
\end{abstract}

Keywords: consumer, behavior, ethics, local product, attitude, motivation, typology

\section{Introduction}

The fair use is growing steadily and can be for many people a first step towards more responsible practices. However, the purchase and consumption of fair trade are often associated with changes in the political and societal context, suggesting that it is a practice exclusive to consumers in the North. Yet in many developing countries such as Morocco, there is the development of a new mode of social consumption allowing citizens to live in dignity, to assert and develop income-generating activities. It is clear that we are far from the archetype of Western consumer fair, the choice is primarily based on labels and distribution channels. The urban/rural logic replaces the linking of Northern consumers to producers in the South. Thus we have found it useful to conduct a study of the responsible behavior of the Moroccan consumers through the purchase of products offered by cooperatives of rural women in the region of Marrakech / Tensift. The aim is to show that the fair purchase based on the principle of responsibility, social justice, fairness and morality does not depend on income and level of economic development but is based on universal moral values that result in solidarity purchase and respect for other's work.

This article is the first step to answer these questions:

- What attitude do socially responsible consumers in morocco adopt? to adopt socially responsible consumers Morocco?

- What are the motivations and brakes of socially responsabile purchase?

We start this article with a review of the literature on consumer marketing as it is reviewed by the authors by showing that it can be understood as both a collective and an individual phenomenon. We will focus later on socially responsible consumer (no comma here) characteristics and variables that influence behavior. In a second step, we present the empirical study including the methodology, the scale used and results.

\section{Consumption Takes Many Forms}

According to Heilbrunn (2005), consumption includes "a set of identity practices by which people structure their social identity by continuous exchange mechanisms."

Several authors have been interested in the meanings of consumption in marketing (Holt, 1995) and the values it provides to the consumer.

Holt (1995) turned to the meanings and purposes of consumption and identifies four dimensions: consumption as experience (this is subjective and emotional reactions in relation to objects ), used as a game ("the consumer participates in a common experience and merges its business with that of a group"), consumption as integration (the consumer equates the object as a component of its identity) and consumption as classification (consumers use 
the object to position themselves relatively to others). Richins (1994) has focused on public and private meanings of consumers' possessions.

Besides the utilitarian value (Functional aspect of the consumption), he (si tu parles de Richins) identifies the amusement (consumption as source of feelings), the appearance, the spirituality, the status, the self-expression, the interpersonal relationship, the self-realization and the personal story (consumption to structure one's (si tu fais reference à une personne) identity and be situated with regard to others).

Other values of consumption appear in Holbrook's researches (1994); Aurier, Evrard and N' Goala, (2004). Holbrook (1994) defines eight values of consumption. Some of these values are directed to the others: the status, the respect, the spirituality and finally the ethics. In this frame, the consumption is valued for the effects which it produces on the others, in particular because it allows the consumers to be situated with regard to the others (Aurier, Evrard \& N' Goala, 2004). Other values (the efficiency, the excellence, the aesthetics and the set) "are directed to one self".

Table 1 . The values of consumption

\begin{tabular}{|c|c|}
\hline $\begin{array}{l}\text { The public and private meanings of consumer possessions. } \\
\text { Richins (1994) }\end{array}$ & 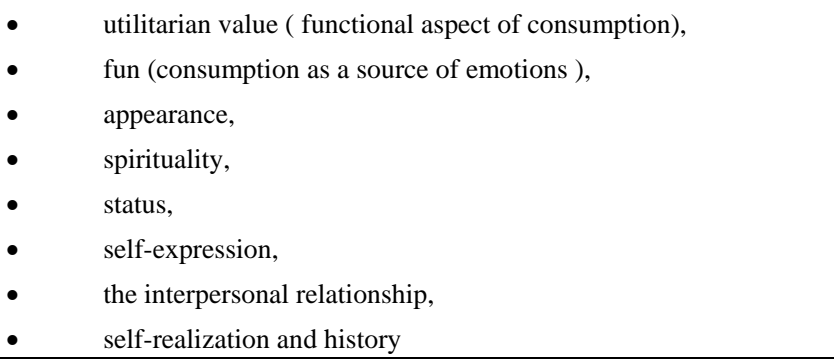 \\
\hline $\begin{array}{l}\text { The values of consumption } \\
\text { The others-oriented values } \\
\text { Holbrook (1994) }\end{array}$ & 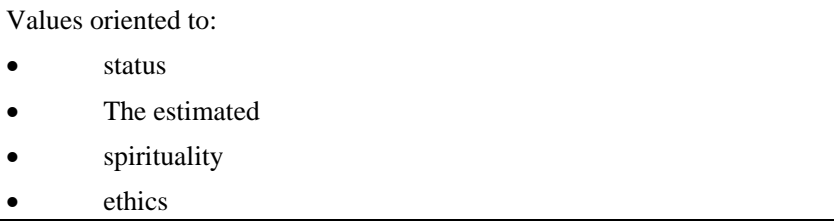 \\
\hline $\begin{array}{l}\text { The values of consumption } \\
\text { Self-oriented values } \\
\text { Aurier, N’Goala Evrard (2004) }\end{array}$ & $\begin{array}{ll}\text { - } & \text { The efficiency } \\
\text { - } & \text { excellence } \\
\text { - } & \text { aesthetics } \\
\text { - } & \text { The game } \\
\end{array}$ \\
\hline The epistemic value (Lai, 1995) & $\begin{array}{l}\text { Consumption allows consumers to satisfy the curiosity and the desire for } \\
\text { knowledge }\end{array}$ \\
\hline
\end{tabular}

Finally Gonzalez and Urban (2007) define consumer (tu as oublié quelque chose ici) as "a set of practices by which the individual, by manipulating objects, gets a share of the functional benefits, emotional, aesthetic and epistemic, the other social benefits in communicating with his fellows to show membership in a group while differentiating itself from others".

All these approaches show that consumption takes many forms and is a representational object.

These contributions of the literature identify five components of consumption as outlined Gonzalez, Korchia, Menuet, and Urban (2009): the emotional dimension (consumption is a "source of emotion and experience of pleasure"), the functional dimension (consumption utilities meet goals and practices), the aesthetic dimension (consumption is sought for "the beauty and expression"), the epistemic dimension (consumption allows consumers to "satisfy the curiosity, the desire knowledge") and finally the social dimension (consumption allows consumers to structure their identity and position themselves in relation to a group).

\section{Responsible Consumption (RC)}

The foundations of responsible consumption refer to philosophical concepts (accountability, ethics, justice, ...) to consider the socio-political field (sustainable development, ...) and managerial topics (business practices).

With regard to managerial considerations, it is clear that even if consumption falls within the private sphere, it is totally related to the practices of companies that are providers of products and services consumed. 
From the managerial point of view, the concepts of "ethics" and or "societal" are an increasingly important in management science research. This interest is reflected in the analysis of business practices through the Corporate Social Responsibility “SRC”. In this context, several managerial tools have been proposed in strategies works including 3P (People - Profit - Planet) (Martinet \& Reynaud, 2004).

At the individual level, there are these 3P in the definition of responsible consumption with the aim to establish a better balance between market activities, protection of the environment and human response to basic needs.

This notion of ethics dismisses (je ne suis pas sure que ce soit le bon terme; verifie. Je pense plutôt à 'refers' mais cela dépend du sens que tu souhaites donner à ta phrase) to a new field of study in consumer behavior and in Marketing.

\subsection{Responsible Consumption and Social Economy: Individual and Collective Phenomena}

Referring to the social economy, consumption is mainly responsible to the "collective" by an individual choice of consumption (je n'ai pas compris cette phrase, elle n’a pas de sens en anglais). Responsible drinking (tu veux dire boire) through the absence of consumption, the consumption of a product or service, or consumption of a product or service offered by a non-capitalist, or a combination of one or more of these. It also responds to at least one of the following three criteria:

a. The reduction in consumption, which may include other behaviors such as reuse, recycling;

b. The consumption of products or services with high environmental or social contributions;

c. The consumption of products or services from organizations of social economy, to a transformation of the purpose of the economy.

These criteria are cumulative and not hierarchical. Together, they embrace the six Rs: reduce, reuse, recycle, rethink our value system, restructure our economic systems and redistribute resources equitably.

Table 2. Consumption and social economy

\begin{tabular}{ll}
\hline Reduce & Rethinking \\
\hline Reuse & Restructure systems \\
\hline Recycle & Equitably redistribute \\
\hline
\end{tabular}

\subsection{Responsible Consumption (RC) for Consumption Socially Responsible (SRC)}

When considering the social dimension of the RC, there are many definitions, the most used are presented in the following table.

Table 3. Definitions of socially responsible consumption

\begin{tabular}{ll}
\hline \multicolumn{1}{l}{ The definitions of socially responsible consumption } \\
\hline Webster 1975 & $\begin{array}{l}\text { socially conscious consumer takes into account the public consequences of private consumption, which } \\
\text { tries to use its purchasing power to induce change in society }\end{array}$ \\
\hline Roberts (1995) & $\begin{array}{l}\text { socially responsible consumer is one who buys goods or services they perceive as having a positive (or } \\
\text { least bad) of its environment and uses its purchasing power to express his social concerns }\end{array}$ \\
\hline $\begin{array}{l}\text { François-Lecompte and } \\
\text { Valette-Florence (2004) }\end{array}$ & $\begin{array}{l}\text { environment or on society and / or use of the purchasing power to express social or environmental } \\
\text { concerns }\end{array}$ \\
\hline $\begin{array}{l}\text { Brown, Dacin, 1997; Mohr, Webb } \\
\text { and Harris, 2001; Sen et }\end{array}$ & $\begin{array}{l}\text { Socially responsible consumption is purchasing when it depends on the degree of social responsibility } \\
\text { of companies }\end{array}$ \\
\hline Bhattacharya, 2001 & Socially responsible consumption is restricted consumption solidarity \\
\hline Lar (2009) & $\begin{array}{l}\text { all the voluntary acts within the sphere of consumption made following the awareness of negative } \\
\text { consequences considered in consumption on the outside world (outside the scope or impact the } \\
\text { functionality of the goods / services purchased or self-interest immediate) }\end{array}$ \\
\hline
\end{tabular}

Referring to the work of Roberts (1995) one can identify two dimensions of socially responsible consumption: 
(a) an environmental dimension: it is to avoid buying products that have a negative effect on the environment.

(b) a social dimension: it is to avoid buying products from companies that have a negative impact on the welfare of society.

Among the practices considered to be responsible include:

- Reduced consumption: Energy Efficiency, Simplicity voluntary reduction, recycling, reuse and recovery of waste, green roofs, Active Transportation, ...).

- Purchase of products or services with high environmental or social contribution: Local Food and supply management in agriculture (organic, Green Building, Products certified as "fair," Clothing "ethical”, Corporate Social Responsibility (SRC).

- Purchase of products or services by the social economy, community supported agriculture, co-operative (food, housing, domestic help, funeral service, savings and credit, hardware, etc.).

This last practice is the one we deal with in our researche. So we will define responsible drinking (drinking veut dire boisson en anglais c'est ce que tu veux dire?) as a purchase based on social motivations rather than on individual motivations.

\subsection{The Study of the Socially Responsible Consumer}

To measure the practices of responsible consumption, Francois Lecompte (2005) adopted a scale that isolates five dimensions: (1) the behavior of the company ("refuse to buy from companies whose behavior is deemed irresponsible") (2) the purchase of shares, (buying products of which "part of the price will return to a good cause"), (3) the desire to help small businesses ("do not buy everything in supermarkets and to live small traders"), (4) consideration of the geographical origin of products ("willingness to favor the products of the community") and finally (5) reducing the volume of consumption ("consumer avoids of" too much "and tries to eat up to do things themselves").

The application of this scale also allowed the isolation of several consumer groups according to their socially responsible practices in SRC. And Francis Lecompte and Valette -Florence (2004) propose a typology of four groups: "socially responsible", the "alert", the "low SRC" and "traditionalists". The study of CREDOC (Croutte, Delpal \& Hatchuel, 2006) distinguishes six groups of individuals according to their sensitivity to the social commitments of businesses.

On the other hand, always in the context of the socially responsible consumer study, several researchers have tried to apply theories from social psychology to explain the behavior including the research of Ferran and Robinot Giannillioni.

They have applied a model which enriched the theory of planned action that is the extended model behavior led by a goal (EMGB, Perugini \& Bagozzi, 2001). They were able to verify the explanatory power of this model by analyzing data from a survey of a sample of 413 students.

Table 4. Theoretical basis of SRC

\begin{tabular}{ll}
\hline $\begin{array}{l}\text { The Theory of Reasoned Action (TRA) } \\
\text { Ajzen and Fishbein (1980) }\end{array}$ & $\begin{array}{l}\text { Attitudes and beliefs derived from the information available. } \\
\text { The concept of intention can understand the voluntary control of the individual. }\end{array}$ \\
\hline $\begin{array}{l}\text { Theory of Planned Action (TPA) } \\
\text { Ajzen and Madden (1986) and Ajzen }\end{array}$ & $\begin{array}{l}\text { The concept of perceived control refers to the ease or difficulty seen to perform the behavior. } \\
\text { Consumers think it will not encounter any significant difficulties in performing his act, behavioral } \\
\text { intention will be even stronger. }\end{array}$ \\
\hline $\begin{array}{l}\text { The extended model behavior led by a } \\
\text { goal }\end{array}$ & $\begin{array}{l}\text { Behaviors are not an end in themselves and they are subject to the achievement of a goal. } \\
\text { Cognitive determinants to take into account the two levels that are the motivational aspect through } \\
\text { (EMBG) (Perugini \& Bagozzi, 2004). }\end{array}$ \\
\hline
\end{tabular}

After this review of the literature, we can conclude that consumption is an individual and collective phenomenon, the concepts of "ethics" and "societal" are the basis of the SRC and then we can speak of several types of socially responsible consumers.

The following questions have guided the empirical study:

(a) Can we confirm the existence of different profiles of socially responsible consumers in the Moroccan context?

(b) How does Moroccan consumer behavior differ in terms of motivation? 


\section{The Empirical Study}

The quantitative study conducted with a convenience sample of 163 people was aimed to answer these questions:

- What is the attitude of the Moroccan consumers towards "fair"products?

- Can we confirm the existence of different profiles of socially responsible consumers in the Moroccan context? And how does their behavior differ in terms of motivation?

In drafting the questionnaire, we relied on the dimensions isolated by Francis Lecompte (2005): the purchase of products - share (buying products that "part of the price will return to a good cause"), the desire to assist small businesses, taking into account the geographical origin of products ("willingness to favor the products of the community").

We consider in this study that the sensitivity to social responsibility can be understood in terms of motivation to buy: a consumer and will be considered as socially responsible as the main motivation to buy is a moral and social and non-material (related the product). Ce paragraphe n'est pas clair, je ne peux pas corriger si je ne comprends pas le sens.

The analysis was performed using SPSS software by conducting factor analysis and cluster.

\subsection{The Products Studied}

Fair trade products refer to the branch ethics of responsible consumption and "fair". Products that come from the EC respond to principles including a fair price, a direct exchange and a long-term commitment. Products of the social economy are in this category.

The products of the social economy will be those produced and marketed by associations and cooperatives in the region Tensift Marrakech. These products cover many different realities: (WFP, weaving, cereals, honey...), but all have the advantage of being natural and part of the culture and heritage. The list of selected products is stopped after a series of interviews with members of cooperatives.

Meetings conducted with these producers have found that these small producers have never had power over pricing. It is often the intermediaries that impose prices.

To date, associations and cooperatives studied often use indirect distribution network (intermediaries) for their products. They recognize, however, that this method is not in their favor because they are forced to accept low profit margins.

\subsection{The Results of the Study}

Analysis of data collected allows us to provide answers to questions in terms of attitude, motivation and profile types.

4.2.1 Knowledge and Perception

- Poor knowledge of fair trade as a means of exchange and a degree of information considered very low by the interviewees.

- Nearly 30\% cited lack of information on these products as a barrier to purchase.

The result of the study is that the idea that the interviewees have of this type of exchange is quite positive. As for the core values associated with this mode of exchange, they are: a good deed for $20.7 \%$ of respondents, a charity for $13 \%$ of the sample and finally $12.4 \%$ find in fair trade one way to respect small producers.

\subsubsection{The Motivations and Obstacles}

In terms of motivations, the study revealed the following reasons:

- The quality and taste (24\%)

- A good deed (23\%)

- Help small producers (21\%)

We note that the main reason respondents have to purchase these products are individual and functional (product), while the social reasons come in the second and third positions in terms of citations.

As for the reasons that discourage respondents to buy fair trade products, they refer to (1) the lack of information about the product, (2) the difficulties in finding these products, or (3) the limited choice. 
We found that those who buy for moral reasons are not necessarily those who spend the most, and the basket monthly average is between 500 and $1000 \mathrm{DH}$ as shown in the following factor analysis.

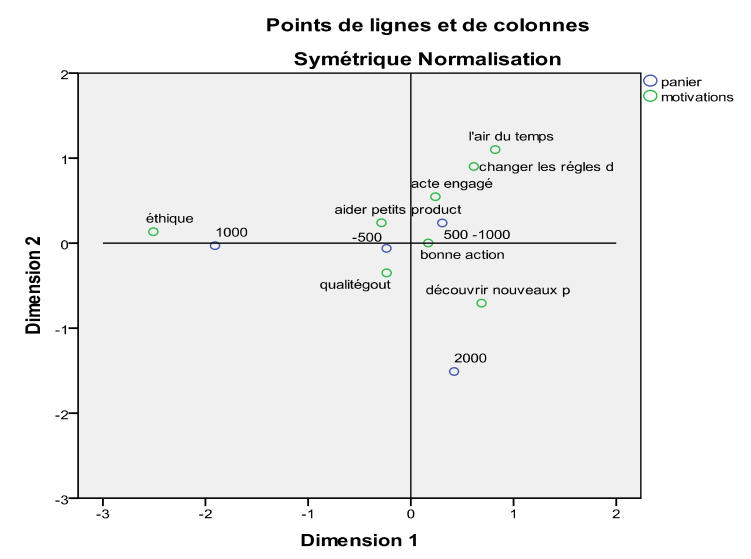

Figure 1. Motivations of the SRC

\subsubsection{Types of Consumers}

An ascending hierarchical classification performed using the dimensions chosen allowed us to make a typology on the analysis of the dendrogram. We have selected the following groups:

Table 5. Types of consumers

\begin{tabular}{lll}
\hline $\begin{array}{l}\text { The committed (10\%) } \\
\text { very favorable }\end{array}$ & $\begin{array}{l}\text { - Information } \\
\text { - Packaging }\end{array}$ & $\begin{array}{l}\text { Ethics } \\
\text { act committed }\end{array}$ \\
\hline The trendy (27\%) & - Information & In the air time \\
& - Packaging & \\
The support (36\%) & - Taste & - Quality \\
& - Quality & - Gout \\
& - Price & - Good action \\
\hline The suspicious (27\%) & They reject: & Ethics \\
& - Quality & Air time \\
\hline
\end{tabular}

To achieve this we have, initially, conducted a principal component analysis with orthogonal rotation to identify two dimensions: first, packaging, product information and other apart from the quality, taste and price. Then we have an ascending hierarchical classification that identified classes. We have chosen four classes.

\section{Discussion of Results and Conclusion}

Our results suggest that consumers have a vision of SRC which is similar to that from the literature.

However, when buying individual motivation is premium and motivation to help small producers and to improve their lives is secondary.

The rejection of this product category can be explained by respondents by:

- lack of information

- lack of choice

- $\quad$ problem of accessibility

- Problem of trust

This article was also intended to present a typology of Moroccan socially responsible consumers to better understand their behavior and motivations. The data analysis allowed us to retain these four dimensions four factors have formed the basis for the construction of a typology showing four groups.

Concerning the limits of this work, we can mention the fact to work on data from the respondents' statements. The results probably overestimate the phenomenon of responsible consumption which remains marginal in our society. 
Based on the results of this exploratory study aims, we intend to deepen our research in order to propose an integrative model taking into account other variables to better understand the consumer socially responsible, and isolating the cognitive, emotional and conative attitude and behavior.

We also expand the scope of investigation and reach consumers in other parts of the kingdom, to test the version of the scale used.

Finally, given the differences in wealth and significant positive changes in our economy that are most favorable to the upper class as the poorest, the development of this mode of RC allows small producers to benefit from fair and sustainable income.

However, the lack of information and lack of awareness of SRC issues in Moroccan consumers can stop this development.

\section{References}

Ferran, F., \& Robinot, E. (2009). The extended model of goal-directed behavior by applied to the purchase of fair trade: a first exploration. 14th Days of Marketing Research of Bourgogne.

Francois-Lecompte, A., \& Valette-Florence, P. (2006). Learn more about the socially responsible consumer. Journal of Marketing, 41, 67-80.

Holbrook, M. B. (1994). The nature of customer value: an axiology of services in the consumption experience. dans Rust R. T. \& Oliver R. L., Service quality: new directions I.

Holbrook, M. B. (1996). Customer value: a framework for analysis and research. Advances in Consumer Research, 23, 138-142.

Holbrook, M. B. (1999). Introduction to consumer value. in M. B. Holbrook (Coord.), Consumer value. A framework for analysis and research. Londres, Routledge, 1-28. Holbrook M. B. \& Hirschman E. C. (1982), The experiential aspects of consumption: consumer fantasies.

Holbrook, M. B., Chestnut, R. W., Oliva, T. A., \& Greenleaf, E. A. (1984). Feelings, and fun. Journal of Consumer Research, 9(2), 132-140. http://dx.doi.org/10.1086/208906

Holt, D. B. (1995). How consumers consume: a typology of consumption practices. Journal of Consumer Research, 22(1), 1-16. http://dx.doi.org/10.1086/209431

Lai, A. W. (1995). Consumer values, products benefits and customer value: a consumption behavior approach. Advances in Consumer Research, 22, 381-388.

Nil Özçag Lar. (2009). What sense do they charge consumers for their consumption? Approach by the life stories. Research and applications in Marketing review, 24(3).

Richins, M. L. (1994). Valuing things: the public and private meanings of possessions. Journal of Consumer Research, 21(3), 504-521. http://dx.doi.org/10.1086/209414

Sirieix, L., \& Filser, M. (2002). Valuing the experience of consumption away from home: the contribution of theorieslooking for variety and enchantment. Proceedings of the 1st day of Norman Consumer Research, Rouen, 264-278. 